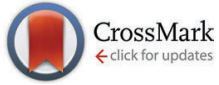

Cite this: Chem. Commun., 2015, 51,431

Received 22nd September 2014, Accepted 11th November 2014

DOI: $10.1039 / c 4 c c 07489 k$

www.rsc.org/chemcomm

\section{Ultralow-intensity near-infrared light induces drug delivery by upconverting nanoparticles $\dagger$}

\author{
Shuqing He, ${ }^{a}$ Kristina Krippes, ${ }^{a}$ Sandra Ritz, ${ }^{a}$ Zhijun Chen, ${ }^{a}$ Andreas Best, ${ }^{a}$ \\ Hans-Jürgen Butt, ${ }^{a}$ Volker Mailänder ${ }^{a b}$ and Si Wu*a
}

\begin{abstract}
Mesoporous silica coated upconverting nanoparticles are loaded with the anticancer drug doxorubicin and grafted with ruthenium complexes as photoactive molecular valves. Drug release was triggered by $974 \mathrm{~nm}$ light with $0.35 \mathrm{~W} \mathrm{~cm}^{-2}$. Such low light intensity minimized overheating problems and prevented photodamage to biological samples.
\end{abstract}

Light has been used for therapy for thousands of years. In modern nanomedicine, light is used to trigger drug release from photosensitive nanocarriers. ${ }^{1}$ For most photosensitive nanocarriers, photoreactions are induced by UV or visible light. ${ }^{1}$ Compared to UV and visible light, near-infrared (NIR) light is more suitable for biomedical applications since NIR light is able to penetrate deeper into tissues and causes less damage. One approach to achieve NIR-triggered drug release is to use simultaneous two-photon absorption to induce photoreactions in nanocarriers. However, this approach is inefficient even when high-intensity femtosecond lasers (pulse intensity $\left.>10^{6} \mathrm{~W} \mathrm{~cm}^{-2}\right)^{2}$ are used because of the low two-photon absorption cross sections of typical chromophores.

An alternative approach to achieve NIR light-triggered drug release is based on lanthanide-doped upconverting nanoparticles (UCNPs). ${ }^{3}$ UCNPs convert NIR light ( $\left.\sim 980 \mathrm{~nm}\right)$ to UV and visible light that can subsequently trigger useful photoreactions (Fig. 1a). This process is called UCNP-assisted photochemistry (Fig. 1a). ${ }^{3 d}$ Compared to simultaneous two-photon absorption, UCNPs can be excited by continuous-wave NIR laser diodes with relatively low intensity. There are two requirements for UCNP-assisted photochemistry. First, upconversion requires an excitation intensity which exceeds a certain threshold. ${ }^{4}$ Second, a suitable photosensitive compound absorbs upconverted light. The reported excitation intensity for UCNP-assisted photochemistry is usually several to several hundred $\mathrm{W} \mathrm{cm}^{-2}$ (Table S1, ESI $\dagger$ ). ${ }^{3 b, c, e, 5}$ However, according

\footnotetext{
${ }^{a}$ Max Planck Institute for Polymer Research, Ackermannweg 10, 55128 Mainz, Germany.E-mail: wusi@mpip-mainz.mpg.de

${ }^{b}$ III. Medical Clinic, University Medicine of the Johannes-Gutenberg University Mainz, Langenbeckstr. 1, 55131 Mainz, Germany

$\dagger$ Electronic supplementary information (ESI) available. See DOI: 10.1039/ c4cc07489k
}
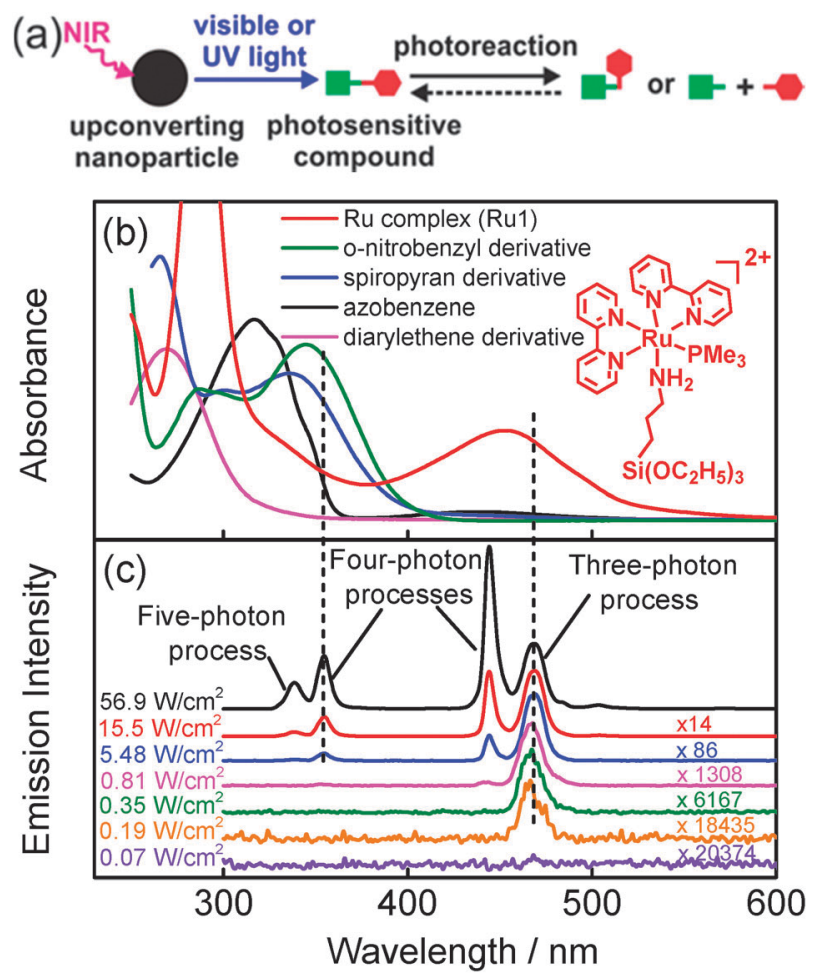

Fig. 1 (a) Schematic illustration: upconverting nanoparticles (UCNPS) convert near-infrared (NIR) light to UV or visible light, which induces photoreactions of photosensitive compounds. (b) UV/Vis absorption spectra of five widely used photosensitive compounds. Inset: chemical structure of the Ru complex (Ru1). (c) Emission spectra $\left(\lambda_{\text {ex }}=974 \mathrm{~nm}\right.$ ) of $\mathrm{NaYF}_{4}: \mathrm{TmYb} \mathrm{aNaYF} \mathrm{U}_{4}$ UCNPs under different excitation intensities. The emission intensity is normalized at $470 \mathrm{~nm}$.

to the American national standard for safe use of lasers, NIR lasers with the intensity of several $\mathrm{W} \mathrm{cm}^{-2}$ are dangerous. ${ }^{6}$ Under continuous exposure to $980 \mathrm{~nm}$ light, the maximum permissible

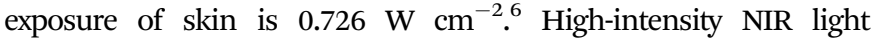
can cause overheating problems and photodamage to biological samples. For example, the overheating effect induced by $980 \mathrm{~nm}$ light at $6 \mathrm{~W} \mathrm{~cm}{ }^{-2}$ can cause cell death within $5 \mathrm{~min}^{7}$ The required 
high excitation intensity of UCNP-assisted photochemistry hinders its biomedical applications. To prevent damage to biological samples due to the NIR laser, it is highly desirable to reduce the light intensity for UCNP-assisted photochemistry.

Herein, we demonstrate a strategy to reduce the NIR light intensity for UCNP-assisted photochemistry to a medically harmless dose. We show that $974 \mathrm{~nm}$ light with $0.35 \mathrm{~W} \mathrm{~cm}^{-2}$ is able to trigger drug release based on UCNP-assisted photochemistry. To the best of our knowledge, $0.35 \mathrm{~W} \mathrm{~cm} \mathrm{~cm}^{-2}$ is the lowest reported intensity for UCNP-assisted photochemistry (Table S1, ESI $\dagger$ ). This light intensity is also lower than the maximum permissible exposure of skin $\left(0.726 \mathrm{~W} \mathrm{~cm}^{-2}\right)$. Overheating problems are minimized and photodamage to biological samples is prevented at such a low light intensity. We fabricated a drug delivery system by loading of mesoporous silica coated UCNPs with doxorubicin. As photoactive molecular valves, blue-light-cleavable ruthenium $(\mathrm{Ru})$ complexes are grafted to the surface of the nanoparticles. The required NIR intensity was that low because a three-photon process is sufficient to create the required blue photons and to induce the photocleavage of Ru complexes. Usually, a four-photon NIR-to-UV upconversion is applied to induce photoreactions of UV-sensitive compounds.

The concept in UCNP-assisted photochemistry entails that a photosensitive compound absorbs the upconverted light. Therefore, the absorption of photosensitive compounds should overlap with the emission of UCNPs (Fig. 1a). We studied absorption of five commonly used photosensitive compounds (Fig. 1b); their chemical structures are shown in Fig. S1 (ESI $\dagger$ ). The metal-to-ligand charge transfer band of the Ru complex (Ru1) is at $\sim 453 \mathrm{~nm}$ (Fig. 1b). Photocleavage of Ru1 can be induced by blue light (Fig. S12, ESI $\dagger$ ). ${ }^{8}$ Like most reported photosensitive compounds, ${ }^{1}$ the absorption bands of the other four compounds are in the UV region. Their photoreactions are induced by UV light.

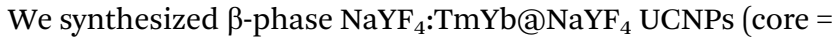
$\mathrm{NaYF}_{4}: 0.5 \mathrm{~mol} \% \mathrm{Tm}^{3+}: 30 \mathrm{~mol} \% \mathrm{Yb}^{3+}$; shell $=\mathrm{NaYF}_{4}$ ) (Fig. S2-S5, $\mathrm{ESI} \dagger$ ), which are some of the most efficient UCNPs known to date. ${ }^{9}$ At high excitation intensities $\left(\geq 5.48 \mathrm{~W} \mathrm{~cm}^{-2}\right)$ with a $974 \mathrm{~nm}$ laser, the UCNPs emit both blue and UV light (Fig. 1c). At low excitation intensities (0.19-0.81 $\mathrm{W} \mathrm{cm}^{-2}$ ), only blue light is emitted (Fig. 1c). The relative intensity of the emission depends on the excitation intensity because the photon numbers for excitation of different emissions vary. ${ }^{10}$ The excitation thresholds for ${ }^{1} \mathrm{I}_{6}-{ }^{3} \mathrm{~F}_{4}$ transition (340 nm, a five-photon process ${ }^{10}$ ), ${ }^{1} \mathrm{D}_{2}-{ }^{3} \mathrm{H}_{6}$ transition (360 nm, a fourphoton process ${ }^{10}$ ), and ${ }^{1} \mathrm{G}_{4}{ }^{3}{ }^{3} \mathrm{H}_{6}$ transition (470 nm, a three-photon process $^{10}$ ) are 5.48, 2.22, and $0.19 \mathrm{~W} \mathrm{~cm}^{-2}$, respectively (Fig. 1c and Fig. S6, ESI $\dagger$ ). Thus, blue emission at $470 \mathrm{~nm}$ still retains and UV emission completely vanishes at excitation intensities below $2.22 \mathrm{~W} \mathrm{~cm}^{-2}$ and above $0.19 \mathrm{~W} \mathrm{~cm}^{-2}$. Out of the five photosensitive compounds, the upconverted blue light at $470 \mathrm{~nm}$ overlaps with the absorption band of Ru1 only (Fig. 1b and c). Therefore, it is only possible to excite the photoreaction of Ru1 at low excitation intensity e.g. $0.35 \mathrm{~W} \mathrm{~cm}^{-2}$.

Based on our hypothesis, we prepared a NIR light-triggered drug delivery system by grafting mesoporous silica coated UCNPs with Ru1 (Fig. 2). UCNPs were coated with mesoporous silica (UCNP@ $\mathrm{mSiO}_{2}$ ) by a sol-gel reaction. ${ }^{11}$ The mesoporous silica is the drug carrier. $^{11}$ The grafted $\mathrm{Ru}$ complexes act as molecular valves. ${ }^{12}$

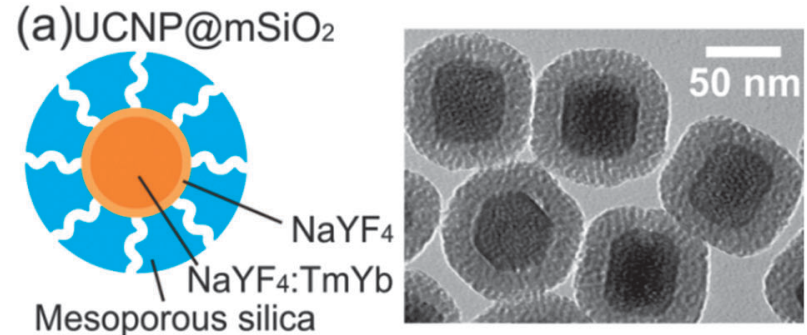

(b) DOX-UCNP@mSiO2-Ru
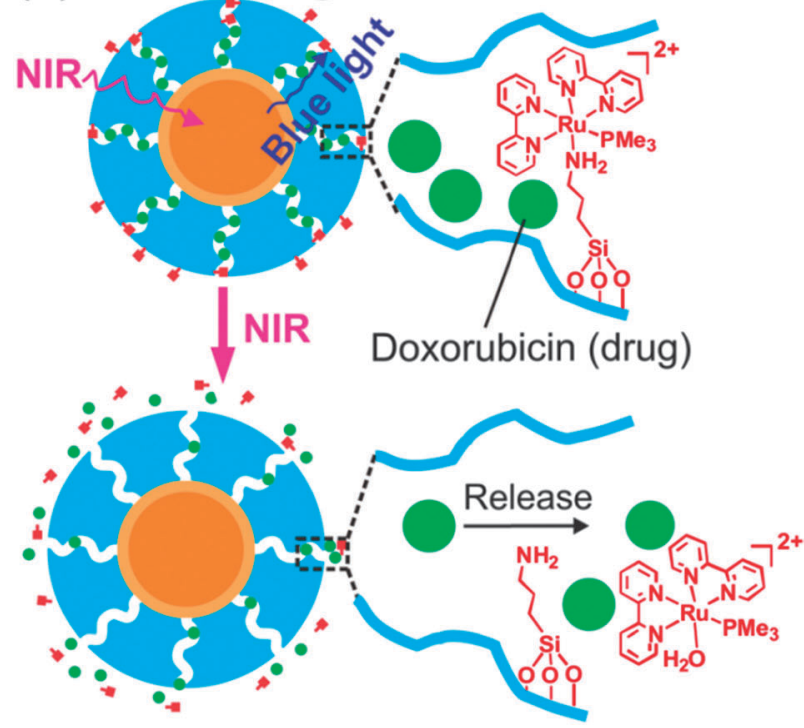

Fig. 2 (a) Schematic model and TEM image of UCNPamSiO 2 nanoparticles. (b) Schematic illustration: upconverted blue luminescence triggers cleavage of $\mathrm{Ru}$ complexes and release of doxorubicin from DOX-UCNPamSiO $-\mathrm{Ru}$ nanoparticles.

The average diameter of UCNP@mSiO ${ }_{2}$ measured by TEM and dynamic light scattering was $92 \mathrm{~nm}$ and $89 \mathrm{~nm}$, respectively (Fig. 2a and Fig. S2 and S3, ESI $\dagger$ ). The average thickness of the mesoporous silica shell was $21 \mathrm{~nm}$ (Fig. S2, ESI $\dagger$ ). Powder X-ray diffraction confirmed that the UCNPs are hexagonal in phase (Fig. S4, ESI $\dagger$ ). The average pore size and the Brunauer-EmmettTeller (BET) surface area of $\mathrm{UCNP} @ \mathrm{mSiO}_{2}$ were $2.6 \mathrm{~nm}$ and $316 \mathrm{~m}^{2} \mathrm{~g}^{-1}$, respectively (Fig. S7, ESI $\dagger$ ). UCNP@ $\mathrm{mSiO}_{2}$ nanoparticles were loaded with the anticancer drug doxorubicin and grafted with Ru1 to form DOX-UCNP@mSiO ${ }_{2}-\mathrm{Ru}$ (Fig. 2b). The drug loading efficiency, measured by fluorescence spectroscopy and UV/Vis absorption spectroscopy, was $2.36 \%$ and $2.52 \%$ (23.6 and $25.2 \mu \mathrm{g}$ doxorubicin in $1 \mathrm{mg}$ nanoparticles), respectively (Fig. S17, ESI $\dagger$ ). The successful grafting of $\mathrm{UCNP} @ \mathrm{mSiO}_{2}$ with Ru1 was confirmed by ${ }^{29}$ Si MAS solid-state NMR spectroscopy, UV/Vis absorption spectroscopy and FTIR spectroscopy (Fig. S8-S10, ESI $\dagger$ ). UV/Vis absorption spectroscopy shows that $7.6 \mu \mathrm{g}$ Ru1 was grafted on $1 \mathrm{mg}$ of nanoparticles (Fig. S11, ESI $\dagger$ ).

To demonstrate absorption of upconverted blue light by the $\mathrm{Ru}$ complex, we compared upconversion luminescence spectra of UCNP@ $\mathrm{mSiO}_{2}$ to $\mathrm{UCNP} @ \mathrm{mSiO}_{2}-\mathrm{Ru}$ (Ru1 grafted UCNP@mSiO${ }_{2}$ ) nanoparticles. The intensity of upconversion luminescence at $470 \mathrm{~nm}$ decreased significantly in the spectrum of $\mathrm{UCNP}_{\mathrm{anSiO}}-\mathrm{Ru}$ (Fig. 3a). 

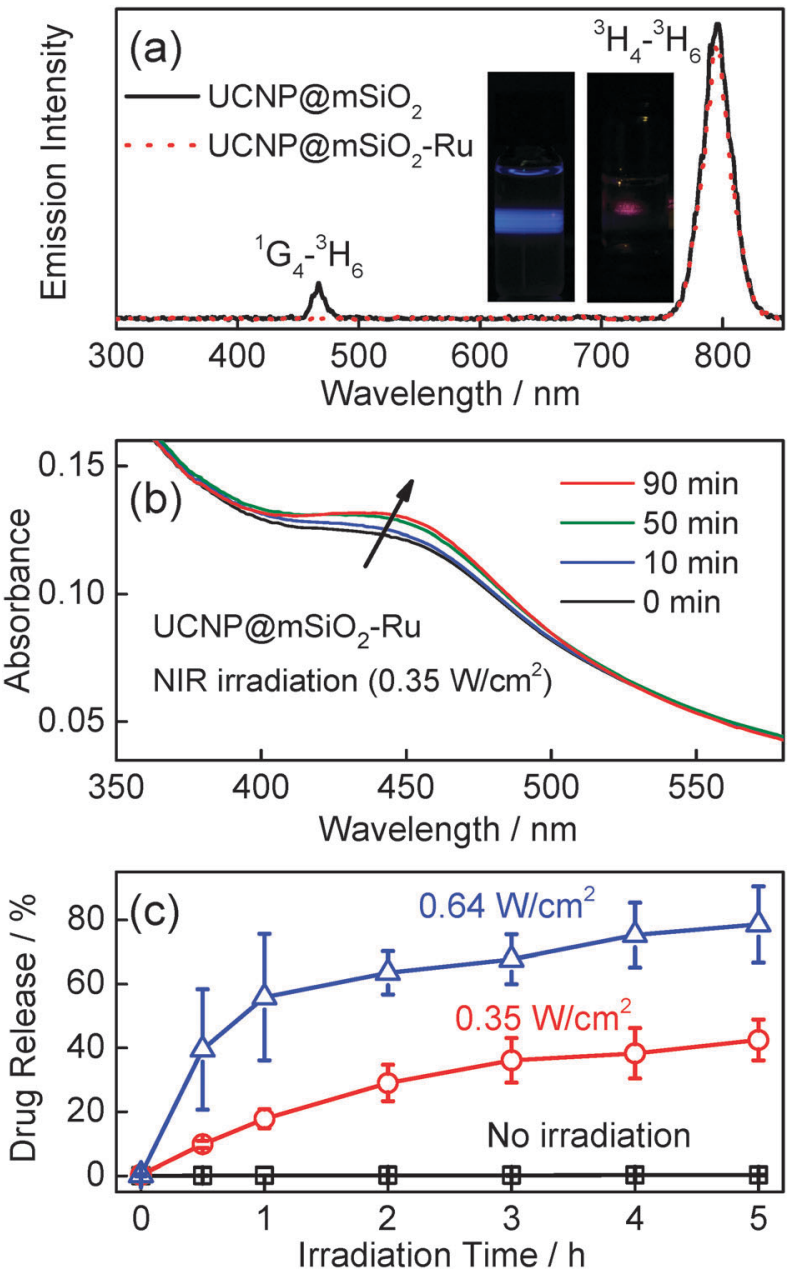

Fig. 3 (a) Emission spectra $\left(\lambda_{\text {ex }}=974 \mathrm{~nm}, 0.35 \mathrm{~W} \mathrm{~cm}^{-2}\right.$ ) of UCNPamSiO 2 and Rul grafted UCNP@mSiO ${ }_{2}$ (UCNPamSiO ${ }_{2}-\mathrm{Ru}$ ) nanoparticles. Inset: photograph of UCNP(amSiO 2 (left) and UCNP(amSiO ${ }_{2}$ - Ru (right) nanoparticles upon a $974 \mathrm{~nm}$ laser exposure. The concentration of Ru complexes in UCNPamSiO ${ }_{2}-\mathrm{Ru}$ was higher than that in DOX-UCNPamSiO ${ }_{2}-\mathrm{Ru}$. (b) UV/Vis absorption spectra of UCNP $\mathrm{amSiO}_{2}$-Ru upon $974 \mathrm{~nm}$ light exposure $\left(0.35 \mathrm{~W} \mathrm{~cm}^{-2}\right)$. (c) Doxorubicin release profile for PEG- and FA-modified DOX-UCNP(amSiO ${ }_{2}-\mathrm{Ru}$ nanoparticles in the dark and upon $974 \mathrm{~nm}$ light exposure. The release profile was measured by fluorescence spectroscopy (Fig. S19, ESI†).

In contrast, the emission at $\sim 800 \mathrm{~nm}$, a spectral region where the $\mathrm{Ru}$ complex has no absorption, still remained. This result proved efficient absorption of the upconverted blue light by the $\mathrm{Ru}$ complex. UV/Vis absorption spectroscopy further confirmed that upconverted blue light can trigger cleavage of the Ru complex (Fig. 3b). $974 \mathrm{~nm}$ light induced a slight redshift of the absorption band of the Ru complex on UCNP@ $\mathrm{mSiO}_{2}-\mathrm{Ru}$ (Fig. 3b). This spectral change is identical to observations for solutions of Ru1 or similar Ru complexes which were exposed to blue light to directly trigger photocleavage (Fig. S12, ESI $\dagger$ ). ${ }^{8 b, c}$ Exposure of Ru1 to $974 \mathrm{~nm}$ light in the absence of UCNPs had no influence on the absorption spectrum (Fig. S13, ESI $\dagger$ ), thus demonstrating that the photocleavage of the Ru complex is triggered by upconversion. Measurements by UV/Vis absorption spectroscopy showed that $974 \mathrm{~nm}$ light $\left(0.35 \mathrm{~W} \mathrm{~cm}^{-2}\right)$ cleaved 59\% Ru complexes from UCNP@ $\mathrm{mSiO}_{2}$-Ru after 5 hour irradiation (Fig. S14, ESI $\dagger$ ).
NIR light-triggered drug release from doxorubicin loaded nanoparticles DOX-UCNP@mSiO ${ }_{2}$-Ru was studied by "mini dialysis" (Fig. S19, ESI $\dagger$ ). Release of doxorubicin was not detected without NIR irradiation. Approximately $42 \%$ of doxorubicin was released after $974 \mathrm{~nm}$ light irradiation with $0.35 \mathrm{~W} \mathrm{~cm}^{-2}$ for 5 hours (Fig. 3c). The release rate increased and $\sim 78 \%$ of doxorubicin was released after $974 \mathrm{~nm}$ light irradiation with $0.64 \mathrm{~W} \mathrm{~cm}^{-2}$ for 5 hours.

As a control experiment, UCNP@ $\mathrm{mSiO}_{2}$ nanoparticles are grafted with a UV-sensitive azobenzene compound instead of the Ru complex (Fig. S30, ESI†). The control experiment showed that no drug release from the azobenzene-grafted nanoparticles could be induced by $974 \mathrm{~nm}$ light with $0.35 \mathrm{~W} \mathrm{~cm}^{-2}$. Approximately $27 \%$ of doxorubicin was released after $974 \mathrm{~nm}$ light irradiation with $7 \mathrm{~W} \mathrm{~cm}^{-2}$ for 5 hours (Fig. S30, ESI $\dagger$ ). This result shows that the required light intensity for drug release in DOX-UCNP@ $\mathrm{mSiO}_{2}$-Ru is much lower. Thus, combining blue-light sensitive Ru complexes with UCNPs could efficiently reduce the excitation intensity for UCNP-assisted photochemistry.

Encouraged by the successful drug release, we investigated NIRinduced drug delivery in cancer cells. For all drug release and cell culture experiments, nanoparticles were modified with poly(ethylene glycol) (PEG) and folic acid (FA) to enhance uptake by HeLa cells. ${ }^{13}$ TEM analyses demonstrated retention of nanoparticle morphology after surface modification (Fig. S15, ESI $\dagger$ ). In cellular studies, HeLa cells were incubated with fluorescence-labeled UCNP@mSiO ${ }_{2}-\mathrm{Ru}$ nanoparticles for 3-6 hours before irradiation. Confocal laser scanning microscopy confirmed uptake of nanoparticles by HeLa cells (Fig. 4a and Fig. S21, ESI $†$ ). Incubation of HeLa cells with UCNP@ $\mathrm{mSiO}_{2}, \mathrm{UCNP} @ \mathrm{mSiO}_{2}-\mathrm{Ru}$ or the doxorubicin loaded nanoparticles (DOX-UCNP@mSiO $2-\mathrm{Ru}$ ) in the dark did not cause a decrease of cell viability, hereby excluding leakage or non-incorporated doxorubicin (Fig. S22, ESI $\dagger$ ). This result is in accordance with the extracellular drug release profile which states that nearly no drugs can be released from the nanoparticles without irradiation (Fig. 3c).

Subsequently, we exposed HeLa cells, incubated for 3-6 h with DOX-UCNP@mSiO 2 -Ru, to $974 \mathrm{~nm}$ light with $0.35 \mathrm{~mW} \mathrm{~cm}^{-2}$. Afterwards, the cells were incubated further for 24 hours. NIR irradiation of DOX-UCNP@mSiO ${ }_{2}$-Ru significantly inhibited the growth of
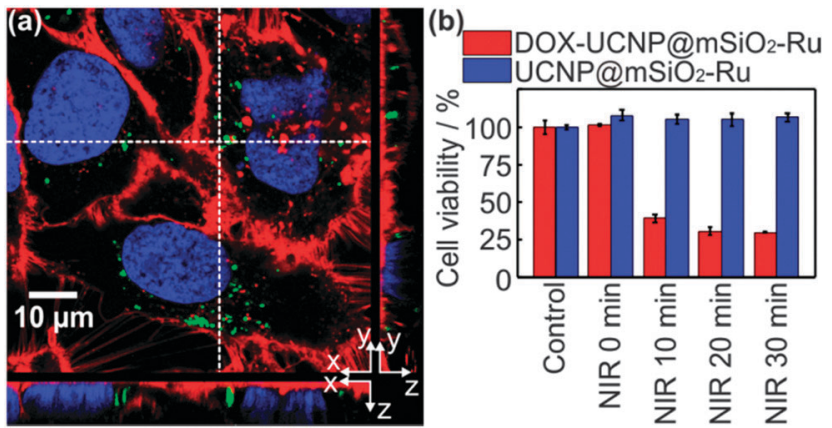

Fig. 4 (a) Confocal laser scanning microscopy image: fluorescence-labeled UCNPamSiO $2-R u$ nanoparticles are taken up by HeLa cells. The nucleus, nanoparticles, and cell membrane are pseudocoloured in blue, green, and red, respectively. The small images on the right side and at the bottom are viewed from $y z$ and $x z$ plains. (b) Effects of light exposure $\left(974 \mathrm{~nm}, 0.35 \mathrm{~W} \mathrm{~cm}^{-2}\right.$ ) on the viability of HeLa cells in the presence of PEG- and FA-modified DOXUCNPamSiO $2-\mathrm{Ru}$ and UCNPamSiO $\mathrm{a}_{2}-\mathrm{Ru}$ nanoparticles. Control: cells in the absence of nanoparticles under room conditions. 

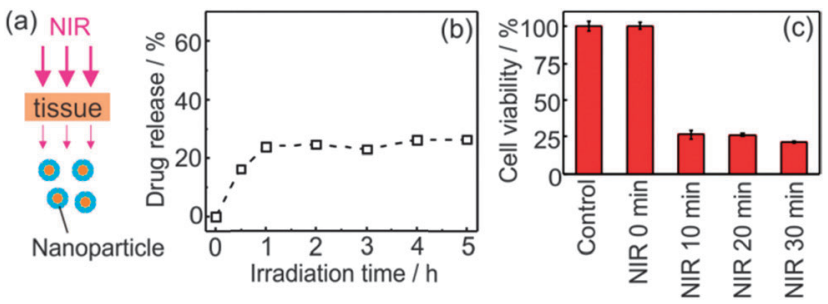

Fig. 5 Schematic model (a), doxorubicin release profile (b), and viability of HeLa cells (c) when a $1 \mathrm{~mm}$ thick pork tissue is placed between $974 \mathrm{~nm}$ light $\left(0.64 \mathrm{~W} \mathrm{~cm}^{-2}\right)$ and PEG- and FA-modified DOX-UCNPamSiO 2 -Ru nanoparticles.

cancer cells (Fig. 4b). Irradiation for 10-30 min reduced cell viability to a value of $40-29 \%$. For comparison, control experiments under identical conditions using $\mathrm{UCNP} @ \mathrm{mSiO}_{2}-\mathrm{Ru}, \mathrm{UCNP} @ \mathrm{mSiO}_{2}$ or no nanoparticles instead of DOX-UCNP@ $\mathrm{mSiO}_{2}-\mathrm{Ru}$ were extensively performed (Fig. 4b and Fig. S23 and S24, ESI $\dagger$ ): NIR light irradiation did not cause significant decrease of cell viability for these control samples demonstrating that cytotoxicity to cancer cells (Fig. 4b) was caused by release of doxorubicin.

We also studied the photothermal effect of $974 \mathrm{~nm}$ light by exposure of water to the laser. The water temperature increased only $2.5{ }^{\circ} \mathrm{C}$ upon irradiation of $974 \mathrm{~nm}$ light under $0.35 \mathrm{~W} \mathrm{~cm}^{-2}$. In contrast, irradiation of $974 \mathrm{~nm}$ light under $2 \mathrm{~W} \mathrm{~cm}^{-2}$ causes a temperature increase of $14{ }^{\circ} \mathrm{C}$ (Fig. S20, ESI $\dagger$ ). This result demonstrates that low NIR intensity can minimize overheating problems caused by NIR light.

We tested the amount of photodamage of pork tissue under $974 \mathrm{~nm}$ light irradiation for $20 \mathrm{~min}$ (Fig. S27, ESI $\dagger$ ). Serious burn wounds were observed when the light intensity is higher than $3 \mathrm{~W} \mathrm{~cm}^{-2}$. When the light intensity is lower than $1 \mathrm{~W} \mathrm{~cm}^{-2}$, no obvious burn wound was observed. Therefore, using lowintensity NIR light is important to prevent tissue damages.

We verified if low-intensity $974 \mathrm{~nm}$ light could induce drug delivery after passing through tissue. We placed a pork tissue between the laser and the nanoparticles. Approximately $26 \%$ of doxorubicin was released after $974 \mathrm{~nm}$ light irradiation with $0.64 \mathrm{~W} \mathrm{~cm}^{-2}$ for 5 hours (Fig. 5b). The released doxorubicin also inhibited the growth of cancer cells (Fig. 5c). The used light intensity $\left(0.64 \mathrm{~W} \mathrm{~cm}^{-2}\right)$ is also lower than the maximum permissible exposure of skin $\left(0.726 \mathrm{~W} \mathrm{~cm}^{-2}\right)$. Thus, low-intensity NIR light could be used to trigger drug delivery and minimize tissue damage in our system.

In conclusion, we demonstrate a strategy to reduce excitation intensity for UCNP-assisted photochemistry. The reported concept for constructing photoresponsive systems that are sensitive to ultralow-intensity NIR light is novel and should be generally applicable to various biomedical applications. We apply this novel concept for low-intensity NIR light-triggered drug delivery. Ru complexes on UCNP@mSiO ${ }_{2}-\mathrm{Ru}$ nanoparticles are cleaved by $974 \mathrm{~nm}$ light with

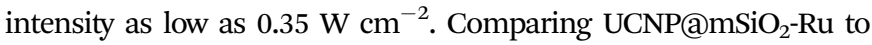
other recently developed systems based on UCNP-assisted photochemistry shows that $0.35 \mathrm{~W} \mathrm{~cm}^{-2}$ is the lowest intensity reported to the best of our knowledge (Table S1, ESI $\dagger$ ). In particular, the intensity is lower than the maximum permissible exposure of skin $\left(0.726 \mathrm{~W} \mathrm{~cm}^{-2}\right)$. We expect the suitability of not only $\mathrm{Ru}$ complexes but also other blue-light-sensitive compounds for UCNP-assisted photochemistry with low excitation intensity. ${ }^{14}$ Low excitation intensity in UCNP-assisted photochemistry minimizes the overheating effect and causes less photodamage to biological samples, both of which are important for biomedical applications.

This work is supported by the Deutsche Forschungsgemeinschaft (DFG, SPP1313 program MA 3271/3-1 and SFB1066). S.H. was supported by the joint program of MPG and CAS. V. M. and S. W. are the senior authors for the biology and chemistry parts, respectively. We thank H. Menges for upconverting luminescence spectra, R. Graf for NMR spectra, and G. Waschatko for preparing tissue.

\section{Notes and references}

1 R. Tong and D. S. Kohane, Wiley Interdiscip. Rev.: Nanomed. Nanobiotechnol., 2012, 4, 638.

2 M. Álvarez, A. Best, S. Pradhan-Kadam, K. Koynov, U. Jonas and M. Kreiter, Adv. Mater., 2008, 20, 4563.

3 (a) B. Yan, J. C. Boyer, N. R. Branda and Y. Zhao, J. Am. Chem. Soc., 2011, 133, 19714; (b) J. Liu, W. Bu, L. Pan and J. Shi, Angew. Chem., Int. Ed., 2013, 52, 4375; (c) Y. Yang, B. Velmurugan, X. Liu and B. Xing, Small, 2013, 9, 2937; (d) M. L. Viger, M. Grossman, N. Fomina and A. Almutairi, Adv. Mater., 2013, 25, 3733; (e) Y. Dai, H. Xiao, J. Liu, Q. Yuan, P. Ma, D. Yang, C. Li, Z. Cheng, Z. Hou, P. Yang and J. Lin, J. Am. Chem. Soc., 2013, 135, 18920.

4 F. Auzel, Chem. Rev., 2004, 104, 139.

5 (a) C. J. Carling, J. C. Boyer and N. R. Branda, J. Am. Chem. Soc., 2009, 131, 10838; (b) J. C. Boyer, C. J. Carling, B. D. Gates and N. R. Branda, J. Am. Chem. Soc., 2010, 132, 15766; (c) C. J. Carling, F. Nourmohammadian, J. C. Boyer and N. R. Branda, Angew. Chem., Int. Ed., 2010, 49, 3782; (d) W. Wu, L. M. Yao, T. S. Yang, R. Y. Yin, F. Y. Li and Y. L. Yu, J. Am. Chem. Soc., 2011, 133, 15810; (e) J. V. Garcia, J. Yang, D. Shen, C. Yao, X. Li, R. Wang, G. D. Stucky, D. Zhao, P. C. Ford and F. Zhang, Small, 2012, 8, 3800; $(f)$ M. K. G. Jayakumar, N. M. Idris and Y. Zhang, Proc. Natl. Acad. Sci. U. S. A., 2012, 109, 8483; $(g)$ Y. M. Yang, Q. Shao, R. R. Deng, C. Wang, X. Teng, K. Cheng, Z. Cheng, L. Huang, Z. Liu, X. G. Liu and B. G. Xing, Angew. Chem., Int. Ed., 2012, 51, 3125; (h) J. Shen, G. Chen, T. Y. Ohulchanskyy, S. J. Kesseli, S. Buchholz, Z. Li, P. N. Prasad and G. Han, Small, 2013, 9, 3213; (i) D. Yang, P. Ma, Z. Hou, Z. Cheng, C. Li and J. Lin, Chem. Soc. Rev., 2014, DOI: 10.1039/c4cs00155a.

6 (a) American National Standard for safe use of lasers, Laser Institute of America, Orlando, FL, 2000; (b) Laser Safety Handbook, Northwestern University, 2011.

7 X. Xie, N. Gao, R. Deng, Q. Sun, Q. H. Xu and X. Liu, J. Am. Chem. Soc., 2013, 135, 12608.

8 (a) V. S. Miguel, M. Álvarez, O. Filevich, R. Etchenique and A. del Campo, Langmuir, 2012, 28, 1217-1221; (b) L. Zayat, M. G. Noval, J. Campi, C. I. Calero, D. J. Calvo and R. Etchenique, ChemBioChem, 2007, 8, 2035-2038; (c) R. E. Goldbach, I. Rodriguez-Garcia, J. H. van Lenthe, M. A. Siegler and S. Bonnet, Chem. - Eur. J., 2011, 17, 9924.

9 F. Wang and X. G. Liu, Chem. Soc. Rev., 2009, 38, 976.

10 (a) G. F. Wang, W. P. Qin, L. L. Wang, G. D. Wei, P. F. Zhu and R. J. Kim, Opt. Express, 2008, 16, 11907; (b) J. F. Suyver, J. Grimm, M. K. van Veen, D. Biner, K. W. Krämer and H. U. Güdel, J. Lumin., 2006, 117, 1 .

11 (a) D. Tarn, C. E. Ashley, M. Xue, E. C. Carnes, J. I. Zink and C. J. Brinker, Acc. Chem. Res., 2013, 46, 792; (b) S. A. Mackowiak, A. Schmidt, V. Weiss, C. Argyo, C. von Schirnding, T. Bein and C. Bräuchle, Nano Lett., 2013, 13, 2576; (c) S. Angelos, E. Johansson, J. F. Stoddart and J. I. Zink, Adv. Funct. Mater., 2007, 17, 2261; (d) C. Li, D. Yang, P. Ma, Y. Chen, Y. Wu, Z. Hou, Y. Dai, J. Zhao, C. Sui and J. Lin, Small, 2013, 9, 4150.

12 (a) N. Ž. Knežević, B. G. Trewyn and V. S. Y. Lin, Chem. Commun., 2011, 47, 2817; (b) M. Frasconi, Z. Liu, J. Lei, Y. Wu, E. Strekalova, D. Malin, M. W. Ambrogio, X. Chen, Y. Y. Botros, V. L. Cryns, J.-P. Sauvage and J. F. Stoddart, J. Am. Chem. Soc., 2013, 135, 11603.

13 G. Baier, D. Baumann, J. M. Siebert, A. Musyanovych, V. Mailänder and K. Landfester, Biomacromolecules, 2012, 13, 2704.

14 Z. Shi, P. Peng, D. Strohecker and Y. Liao, J. Am. Chem. Soc., 2011, 133, 14699-14703. 